\title{
SAN JUAN DE ÁVILA DESDE LA SOCIEDAD Y LA CULTURA ACTUALES
}

FRANCISCO JAVIER DÍAZ LORITE ${ }^{1}$

DOI: https://doi.org/10.52039/seminarios.v57i201-202.332

Bien decía Pablo VI que San Juan de Ávila es un sacerdote y un santo al que se puede calificar de actual y moderno por la pluralidad de facetas que ha vivido y enseñado, y que son luz para los hombres y mujeres de nuestro tiempo? Yo diría que su luz brilla hoy con un resplandor especial porque en la actualidad es mayor la necesidad que tenemos de su ejemplo. La luz ilumina con más intensidad precisamente cuando está más oscuro. La luz que nos aporta San Juan de Ávila brilla hoy ante nuestros ojos con un nuevo y radiante resplandor, no sólo para la Iglesia sino también para la sociedad y para la cultura actuales. Es lucero resplandeciente de la mañana para una sociedad que anhela felicidad, libertad, paz, progreso, etc., a veces por caminos tortuosos y hasta equivocados que al hombre actual le hace sufrir de manera atroz. Incluso cuando los caminos son en parte acertados, como la solidaridad, sentido de colectividad o de aldea global, declaración y conquista de ciertos derechos humanos, búsqueda y reconocimiento de la dignidad de la persona, igualdad, etc., no termina, sin embargo, de llegar a su plenitud pues le falta su raíz última y fundamento primero: Dios. Estamos viviendo una época de cambio o de noche cultural, si se entiende así el conjunto de valores que impregnan una sociedad. Verdaderamente estamos asistiendo al nacimiento de una nueva era, con todo lo que esto trae consigo de trauma y de logros, de crisis dicen otros, en la que para que esta noche se convierta en crecimiento verdadero sin duda necesitamos con urgencia la luz de personajes como San Juan de Ávila ${ }^{3}$.

Muchas son las características comunes a ambas épocas, la suya y la nuestra, aunque sin lugar a dudas no semejantes, que hacen que San Juan de Ávila

1. Delegado del Clero de la Diócesis de Jaén. Doctor en Teología. Además de su tesis doctoral, ha dedicado diversas publicaciones a la figura y la obra de San Juan de Ávila.

2. "San Juan de Ávila es un sacerdote que, bajo muchos aspectos, podemos llamar moderno, especialmente por la pluralidad de facetas que su vida ofrece a nuestra consideración y, por lo tanto, a nuestra imitación», cf. S. JUAN DE ÁvILA, Obras completas, nueva edición crítica, eds. L. Sala Balust-F. Martín Hernández, vol. I, Madrid 2000, 359. Para citar los textos de San Juan de Ávila me referiré siempre a estas Obras completas en 4 vols. de la Biblioteca de Autores Cristianos (BAC Maior).

3. Muchas de las ideas contenidas en este artículo aparecen de forma más extensa en mi libro: F. J. DíAz LoRITE, Experiencia del amor de Dios y plenitud del hombre en San Juan de Ávila, Madrid 2007. 
pueda ser una persona totalmente autorizada para que le pueda dar a la sociedad y cultura de nuestros días claves muy actuales y una palabra de aliento que le ayuden a salir de la noche y vislumbrar la aurora de una ansiada nueva civilización del amor, una verdadera cultura del amor, y en ella estén presentes todos los valores que ansían los corazones sedientos de felicidad, de auténtica realización y progreso personales y comunitarios; en definitiva, de plenitud existencial. Además, podemos decir con toda propiedad que San Juan de Ávila, desde los valores de la fe que ha vivido y predicado, ha sabido crear cultura, la cultura del amor que nace del Evangelio; y esto lo hizo ya en su tiempo y con tanto acierto que se ha ido introduciendo en las venas de la Iglesia y de la sociedad. Esta nueva cultura que nace de la fe, y que no anula los logros humanos, sino que los potencia y fundamenta, es lo que quiero presentar como la aportación más relevante de San Juan de Ávila para la sociedad y cultura actuales. De esta forma, el hombre de hoy encuentra en San Juan de Ávila un poderoso Maestro de vida integral, de realización y crecimiento personal y colectivo que ilumina el presente con la mirada esperanzadora hacia el futuro.

No es nuestro objetivo describir los rasgos de la sociedad y cultura actuales ${ }^{4}$, sino describir las características sobre las que consideramos más importante reflexionar bajo la luz aportada por Juan de Ávila desde su vivencia y predicación.

\section{DIOS, PLENITUD DEL HOMBRE}

Es fácilmente constatable que el hombre de hoy ha querido afianzarse no sólo como centro de la tierra sino de toda la realidad, para lo cual ha descartado de sí y de la cultura la idea de que es criatura, y de que por tanto está ligado a un creador. Hoy su principal objetivo, como ocurrió al acceder a la voz de la serpiente, desde el mismo comienzo de la humanidad, es el de ser dios, "seréis como dioses», aseguraba ella; que en la mentalidad moderna ha pasado en la práctica a significar la pretensión de «vivir como dios»; y para conseguirlo utilizar todos los medios posibles, la explotación sin límites de la misma naturaleza e incluso de los semejantes, de los prójimos. Esto ha llevado a que el hombre haya querido hacer desaparecer a Dios del horizonte de su vida personal y de la sociedad y cultura actual. Ya ni siquiera se le hace necesaria la pregunta sobre Él. Una pregunta que hasta ahora le era necesaria, y que por lo menos merecía una respuesta coherente, en sentido negativo o positivo. Pero el hombre de hoy quie-

4. Señalo sólo algunas obras sobre la relación entre la fe y la sociedad actual: J. L. RuIz DE LA PEÑA, Crisis y apología de la fe. Evangelio y nuevo milenio, Santander 1995; ID., ed. Carlos Díaz, Una fe que crea cultura, Madrid 1997; E. Bueno DE LA FuENTE, España, entre Cristianismo y Paganismo, Madrid 2002; AA. VV., Ser sacerdote en la cultura actual, Santander 2009; F. Sebastián Aguilar, Evangelizar, Madrid 2010; Pontificium Consilium de Cultura, Culturas y fe, Civitas Vaticana; Religión y Cultura, Rev. Trimestral de los PP. Agustinos. 


\section{Juan de Ávila desde la sociedad y cultura actuales}

re quitarla de su vista. No quiere enfrentarse a ella. Simplemente cree que él está destinado a vivir como Dios y basta. El problema de esto es que en realidad, todo hombre sí estaba destinado por el creador a ser como Dios, a anhelar la vida de Dios, a disfrutar de lo que se ha denominado su divinización, que es en lo que realmente consiste la plenitud de lo humano. Esto está impreso en el corazón del hombre por el mismo Dios. Es nuestro destino. El problema es que el hombre quiere llegar a esta meta sin Dios, quiere llegar a su plenitud sin Él, y ve con frustración que, aun poniendo todo su esfuerzo en llegar a una pretendida divinización, no termina de lograrlo ni teniendo todos los bienes del mundo. Es más, experimenta vacío existencial, pues nada ni nadie puede llenar su ser de sentido sino el mismo Dios que por amor lo ha creado.

San Juan de Ávila ha vivido en la mentalidad del renacimiento, donde se comienzan a fraguar estas ideas del valor del hombre y de su puesto primordial en la creación. Ha comprendido y predicado la importancia del hombre que sale de un periodo histórico como es la Edad Media y que comienza a renacer. En este sentido, San Juan de Ávila es un verdadero humanista, pero al mismo tiempo, ha puesto de manifiesto con su vida y predicación que el ser humano no conseguirá su deseada plenitud si no es teniendo en cuenta a Dios en su proyecto personal y comunitario, ya que éste, lejos de ser el enemigo de la realización del hombre, es su garante, su fundamento, su plenitud. Dios es el que ha puesto en su corazón el deseo de llegar a ser como Dios, que es donde reside nuestra plenitud, pero en Él y con Él. Nos hará sentar a la mesa de la divinidad siendo hijos en su Hijo. Jesucristo, con su encarnación, con su muerte y resurrección es la encarnación de la plenitud de lo humano; de manera que siguiendo sus pasos nos llevará a nuestra realización plena. Por eso dirá el apóstol de Andalucía: «El hombre con Dios es como Dios y sin Dios es grandísimo tonto y loco»". Por tanto advierte: "¿Qué es el mundo sin el sol? Una noche oscura. ¿Qué es la gente sin Dios? Una noche oscura»6. E insiste en otro lugar: "¿Qué haremos sin Él sino tornarnos en nada?»?.

San Juan de Ávila es el hombre del verdadero renacimiento, pues sabe que el ser humano no renacerá si no tiene en cuenta a Dios. Es más, sucumbirá él mismo. En realidad es lo que está ocurriendo. A la llamada muerte de Dios por parte de la cultura moderna ha seguido como consecuencia la denominada muerte del hombre. Es el hombre fragmentado y roto que hoy vivimos, quien no encuentra su sustento, pues insistiendo en buscarlo en él mismo no lo halla. El Maestro Ávila ya nos advertía que una de las consecuencias de no amar a Dios era la de ni siquiera ser amigo de uno mismo. Con lo cual se produce una desarmonía interior que el hombre de la sociedad de hoy está experimentando.

5. Carta 2, 19-20: IV, 15.

6. Lecciones sobre 1 San Juan (I), 4, 138-140: II, 129.

7. Carta 64, 86: IV, 286. 
Ya nos decía el Santo Maestro: «El que no ama a Dios, decimos que está perdido de sí y es enemigo de sí»". Por eso dice: "El primer bien, hermano, que te verná por amar a Dios es que te hallarás»9.

San Juan de Ávila enseña además que el hombre en Dios no sólo se halla a sí mismo sino que alcanza su deseada meta: su plenitud, pero no por sí sólo, sino en Dios y con Dios. Es lo que se ha venido en llamar durante siglos, sobre todo en la teología oriental, como su divinización, y lo que hoy se conoce como llegar a nuestra plenitud en nuestra filiación por puro amor de Dios, que nos hace hijos en su Hijo encarnado, muerto y resucitado, llegando «a ser un espíritu con Él y a ser Dios por participación $»^{10}$.

San Juan de Ávila es un hombre de Dios que ha experimentado no sólo su existencia en pura y viva fe, sino su amor entrañable, a Dios como verdadero amigo del hombre, como Dios Amor, al Dios se nos da Él mismo entrañablemente, para que nosotros seamos todo en Él. Por eso Dios no sólo no es la muerte del hombre sino la gloria del hombre y su verdadera plenitud ${ }^{11}$.

VALOR ABSOLUTO PERO RELATIVO DE CADA HOMBRE, POR ENCIMA DE TODA OTRA REALIDAD

En la predicación de San Juan de Ávila está perfectamente claro que el hombre es la cúspide de la creación, pues no sólo es criatura creada a imagen del Hijo, sino que ha sido amado y creado en la divinidad de hijo en el Hijo natural, Jesucristo. Esto fundamenta el valor absoluto de cada hombre. Pero es un absoluto relativo, ya que no puede sustraerse de su referencia a Dios, que es el absoluto absoluto y el garante del valor de cada hombre.

Es de notar el interés de San Juan de Ávila en referirse con mucha frecuencia a sus interlocutores, aunque sean muchos en forma de la segunda persona del singular cuando se refiere especialmente a los beneficios que Dios les otorga. El hombre no es un número más en medio de una masa anónima, sino alguien al que el mismo Dios se dirige en primera persona, alguien a quien Dios ama de manera singular. Dios se da a cada uno como si ningún otro existiera. Dios ha intervenido en la creación de cada uno por puro amor. En realidad, no nos ha creado para luego amarnos, sino que al amarnos nos crea. Es su amor entrañable a cada uno el que le ha movido a crear a cada persona que existe en este mundo. Es decir, nuestro ser es ya una acción especial de Dios que quiere a cada uno de manera singular. San Juan de Ávila insiste en esta acción amorosa de Dios hacia cada persona y no sólo en el acto de la creación, sino que los beneficios

8. Sermón 23, 6: III, 280.

9. Sermón 23, 7: III, 281.

10. Sermón 18, 10: III, 233.

11.F. J. DíAZ LORITE, Experiencia del amor de Dios, 536-537; cf. O. GoNZÁLEZ DE CARDEDAL, La gloria del hombre, Madrid 1985, 68s; R. GuARDINI, Wahrheit des Denkens und Wahrheit des Tuns. Notizen und Texte, 1942-1964, München 1980, 59. 
de la muerte de Cristo, que son universales, son aplicados a cada persona de manera singular. San Juan de Ávila da mucha importancia a esta idea para remarcar el valor de cada persona, incluso merecedora por ella misma de que Cristo se halla ofrecido por amor en la cruz. Pero San Juan de Ávila hace hincapié en que el beneficio es para cada persona en concreto, y así ha de sentirlo cada uno en su interior, por eso dice: «Y si lo que le mandaron hacer por la salud de todos los hombres, le mandaran hacer por cada uno de ellos, así lo hiciera por cada uno como por todos» ${ }^{12}$. Y así ha sentirse y agradecerlo cada uno en su interior debido al «deseo que tuvo de padecer por ti $\rangle^{13}$.

También pone de manifiesto el Santo Maestro la relación íntima y amorosa que cada una de las personas de la Trinidad establece con cada uno de nosotros, pues siendo Dios, cada uno se relaciona con nosotros y mora en nosotros según su propia peculiaridad: el Padre, el Hijo y el Espíritu; y esto con cada persona en particular, que es donde quiere morar ${ }^{14}$.

El hombre tiene para el Apóstol de Andalucía una dignidad inigualable en la creación, puesto que es verdaderamente hijo de Dios al ser amado y enaltecido como hijo en el Hijo natural, Jesucristo. Este valor absoluto del hombre se encuentra siempre ligado a quien se lo otorga: Dios. El hombre no puede apropiarse este valor, porque el absoluto es Dios. Pero eso sí, Dios, lejos de ser contrincante de este valor del hombre, es el que lo fundamenta y lo sostiene. Dios lo ha creado como tal y lo sigue manteniendo en esta dignidad, de manera que si le retirara su favor, el hombre dejaría de tenerlo, pues sólo "en Él vivimos, y nos movemos y tenemos ser $\rangle^{15}$.

\section{UNA MÍSTICA DE LA CREACIÓN, UNA MÍSTICA ECOLÓGICA}

El hombre es cúspide de toda la creación, pero fundamentado en Dios. Si no, el hombre se acaba deshaciendo en nada, y ni siquiera tendrá en cuenta la obra creadora. La creación está puesta al servicio del hombre, de cada hombre, al que San Juan de Ávila le da un valor especial. Toda la creación estaba destinada a servir de casa para el hijo: «'Quiero poner casa a mi hijo'. Estaba todo lo dicho criado; estaba como vacía la casa. Crió al hombre [...] $\rangle^{16}$.

Esto hace, por una parte, que la realidad no se vea al margen de Dios ni de lo que estaba destinada a ser, casa para el que la iba a habitar: el hombre, como cúspide de esa creación. Un hombre que ya estaba destinado a ser hijo en el

12. Tratado del amor de Dios, 7, 244-246: I, 962.

13. Tratado del amor de Dios, 8, 275: I, 963.

14. F.J. DIAZ LORITE, Experiencia del amor de Dios, 283-409.

15. Audi, filia (II), 64, 3: I, 673.

16. Sermón 32, 4: III, 388. Cf. M. LEGIDO, Misericordia entrañable. Historia de salvación anunciada a los pobres, Barcelona 1987, 45. 
Hijo. Es la casa que el Padre ha preparado con esmero para su hijo, el hombre. Esto hace de la creación no algo extraño al hombre sino un auténtico hogar en común armonía con los astros, plantas, animales, etc. Pero, al mismo tiempo, también marca una diferencia. El hombre es la cúspide de esa creación. Él es el único que de entre todos los seres tiene la dignidad de hijo. Bien se refería a esa dignidad y a este valor fundamental del hombre Teilhard de Chardin, y recientemente el prof. Miguel Rojo Sierra, cuando habla del hombre como «autoconciencia del cosmos $»^{17}$. Es decir, aquel a partir del cual el cosmos toma sentido. Se refiere por tanto San Juan de Ávila al valor indiscutible del hombre. Buena perspectiva a tener en cuenta para un mundo como el actual en el que se ha enfatizado tanto el valor de los animales; pero hay que hacerlo en su justa medida, pues hemos llegado a dotarlos a veces de más derechos de los que le otorgamos al mismo hombre.

San Juan de Ávila no presenta a Dios como un ser más de la creación, ni siquiera el Ser por antonomasia, sino el fundamento primero de todos los seres: "iOh Dios que eres sobre todas las cosas y ninguna de ellas de ellas, porque eres sobre todas ellas!» ${ }^{18}$. Y en otro lugar: «Sabed, pues ahondar bien en el ser y fuerzas que tenéis y no paréis hasta llegar al fundamento primero que, como firmísimo e indeficiente y no fundando sobre otro más fundamento de todos, os sustenta que no caigáis en el pozo profundo de la nada, de la cual primero os sacó. Conoced este arrimo que os tiene y esta mano que, puesta encima de vos, os hace estar en pie y confesad con David: Tú, Señor, me heciste, y pusiste tu mano sobre mí $($ Sal 138, 5) [...] Adorad, pues, a este Señor con reverencia profunda como a principio de vuestro ser, y amalde como a continuo bienhechor vuestro y conservador de él, y decilde con corazón y con lengua: 'Gloria sea a ti para siempre, poderosa virtud, en la cual me sustento'» ${ }^{19}$.

El Santo Maestro, al considerar al hombre como punto álgido de la creación, no da al hombre la potestad de atentar contra la naturaleza, pues ésta no es su obra sino obra creadora, por tanto viene de Dios, y a Dios pertenece, por lo que hay que cuidarla entrañablemente.

En realidad, nos habla de la mística de la creación, lo que produce no sólo el respeto por su obra creadora, sino la fuente en la que se basa ese respeto, que no sino el mismo Dios que se nos está dando en todas las cosas que Él nos ha creado por sólo amor. En su obra creadora nos encontramos con el mismo Dios dándosenos, desde los astros y cosas más grandes (sol, luna, estrellas) hasta los más pequeños: "Diréis vos:-Padre, ¿un grano de uvas no es al fin un grano de uvas? -Sí, pero en esa cosa tan poca viene envuelta otra cosa,

17. Cf. M. Rojo SierRa, El hombre cósmico. Aportación al transhumanismo de Julian Huxley, Valencia 1999.

18. Carta 64, 79-80: IV, 286

19. Audi, filia (II), 64: 4: I, 673. 


\section{Juan de Ávila desde la sociedad y cultura actuales}

que es más que cielo y tierra, que es el mesmo Dios. ¿Pensáis que lo ha Dios porque comáis, porque os hartéis, no más? Tierra es lo que nos da, pero otra cosa es lo que nos dice David, sintiendo esto: Quid est homo quod memor es eius, aut quid apponis erga eum [cor tuum]? (cf. Sal 8, 5). ¿Qué cosa es, Señor, el hombre, que te acuerdes de él y pones tu corazón cerca de él? (cf. Job 7 , 17). Mirad, cuanta diferencia va de dar vos a una vuestro corazón o otro don, que tanto va de lo que os da Dios a lo que os dice por aquellas señas; porque éstas os dicen que en el don os dan sus entrañas. ¿Habéislo entendido? Ni creo que tenéis ojos para ve[r]lo ni oídos para oírlo» ${ }^{20}$.

Con lo cual, no sólo hay que tratar el cielo, la tierra, y todo lo que en ellas se contiene con respeto, sino con amor. Pues nuestra adecuada respuesta al amor que allí se encierra, que no es sino Dios mismo dándosenos, lo ha creado por sólo amor para nosotros. Se trata de una auténtica mística de la creación, que va más allá, aunque la incluye de una necesaria y tan actual mística ecológica, que debe ser el fundamento último del urgente respeto medioambiental y ecológico, que el hombre ha roto al creerse dueño de toda la realidad. Sólo de la mística creadora, podrá el hombre poder resituarse como cúspide de la creación y como conservador y con-creador, y no por consiguiente destructor de todo lo creado.

\section{DIOS Y CIENCIA; CIENCIA Y FE; DIOS Y RAZÓN}

Una de las razones de la escisión entre el hombre y Dios de la sociedad actual ha sido el no saber compaginar la fe con la razón, la fe con la ciencia y últimamente, como una derivación de lo anterior, la fe con la técnica ${ }^{21}$. Por una parte, el hombre ha considerado que ante Dios y las verdades por Él reveladas no debía utilizar su razón, porque creía que ante tal misterio, la razón debía ser anulada, pues se debía a Dios en fe «ciega». Esto ha provocado que el hombre se rebelara contra esta idea, pues creía que tenía que dejar atrás algo tan normal y sencillo como la capacidad del raciocinio, que es la que verdaderamente nos hace humanos. También la ciencia y la técnica, producto del raciocinio del hombre se veían como pesos pesados de estos logros humanos que aparecían al menos en contradicción aparente, ya no solo para reconocer la existencia de Dios como creador, sino para aceptar la dependencia que tal criatura debía permanentemente al creador. Pero por otra parte, al descubrir estos logros técnicos por sí mismo el ser humano ha tenido y tiene el peligro de creer que toda la realidad, pues en parte es descubierta y ahora manejada por él, está exclusivamente bajo su dominio, no viendo la necesidad de acudir a un ser superior, ni siquiera para responder a los interrogantes últimos. Esto alimenta en muchos

20. Plática 16, 8: I, 892.

21. Cf. J. L. RuIz de LA PeÑA, Teología de la creación, Santander 1986, 201-218. 
de nuestros contemporáneos lo innecesario de la pregunta por la propia existencia de Dios, por la de los demás seres y por el resto del cosmos, pues creen poder comprehender y controlar toda la realidad prescindiendo de Dios, llegando hasta incluso a acariciar como posible en corto espacio de tiempo la siempre deseada inmortalidad en esta vida debido al rápido desarrollo de los avances técnicos. Sin lugar a dudas, el dominio de la ciencia y de la técnica es hoy cada vez más evidente y está generando un nuevo tipo de hombre.

San Juan de Ávila, hombre renacentista, es luz para saber decir al ser hombre actual que Dios no anula al ser humano, y por tanto su capacidad de razonar y con ella desarrollar la ciencia y la técnica. Él mismo inventó unos artilugios para sacar agua y que incluso patentó en su época ${ }^{22}$. El Santo Maestro ayuda a situar las cosas en su justa medida, de manera que ni la fe se adueñe y anule al hombre, ni el hombre se crea Dios al creer que con son sólo su razón, con su ciencia y técnica es capaz de comprehender y dominar toda la realidad, creyéndose entonces que le corresponde otorgar de sentido a todo lo que existe, con lo que adelanta la posición del verdadero y necesario diálogo y encuentro humilde entre la fe y la razón. Un diálogo que no siempre se ha llevado a cabo con éxito en la historia por distintos malentendidos, desconocimiento mutuo, posiciones demasiado absolutas presentadas con frecuencia como irremisiblemente irreconciliables, etc. Hoy día se están dando pasos en este acercamiento entre fe y razón, tanto por parte de la Iglesia como por un sector del mundo científico, si bien hay que reconocer que éste último no camina al mismo ritmo de acercamiento, pues se cree con poder casi absoluto. Sin duda la Encíclica Fides et Ratio de Juan Pablo II, y los límites de la ciencia que contemplan científicos como K. Popper, etc., contra aquellos que quieren presentar sus descubrimientos a través de sus investigaciones como la verdad única y última para entender, no parte de la verdad sino toda la verdad y tenerla en sus manos, creyéndose los únicos poseedores de la misma, contribuyen a este diálogo fructífero entre fe y razón.

San Juan de Ávila es un hombre bien preparado, tanto en letras como en la técnica, y al mismo tiempo es un hombre de fe, que cree en Dios, un Dios al que no experimenta como opositor de nuestra razón. Es verdad que reconoce que la fe no siempre es entendida por el hombre, pero no porque ésta vaya contra la razón, sino porque es una luz que brilla con tanta fuerza que a veces nos deslumbra. No es por falta de luz o razón por lo que el hombre no llega a entender del todo a Dios y las verdades que Él nos comunica sino porque con frecuencia Él y ellas nos sobrepasan. La verdad de la fe no va contra la razón sino más allá de la razón. A ello dedica el capítulo 32 de Audi, filia, en el que dice a Sancha Carrillo y a todos los lectores: «Es menester que estéis advertida a que, por haber

22. Cf. I. GonZÁLEZ TASCÓN, «Los ingenios hidráulicos del Maestro Juan de Ávila», en ConFERENCIA EPISCOPAl EsPañola, El Maestro Ávila. Actas del Congreso Internacional, Madrid 2730 noviembre 2000, Madrid 2002, 341-353. 
oído que nuestra fe cree cosas que aunque no sean contra razón no se pueden alcanzar por razón, no por eso penséis que el creerlas es cosa contra razón o sin razón »²3. La explicación de esto quedaba ya adelantada en el capítulo anterior al decir que la razón es una luz tan brillante sobre la verdad de Dios y las verdades por él reveladas que no pueden ser captadas totalmente por el hombre, pero no porque éstas no tengan luz sino por la sobreabundancia de ésta: "[...] es lucidísima luz [...] es Luz tan lucida y tan sobreluciente que, como dice San Pablo, mora en una luz que nadie puede llegar a ella [...], porque ningún ojo criado, de hombre o de ángel, puede con su razón alcanzar sus misterios [...] es luz que excede a todo entendimiento sobremanera ${ }^{24}$. No se trata de falta de luz para entender a Dios, sino que nuestro entendimiento no puede llegar a comprenderlo en su plenitud, porque Dios es «un infinito abismo de lumbre» ${ }^{25}$.

Dios nos ha dado la inteligencia para que la utilicemos y entremos en una relación de amor con Él como un tú. Toda la realidad está fundamentada en Dios, Él es quien nos da su sentido último. El hombre con su razón sólo puede aspirar a entender parte de la verdad. La técnica ayuda a perfeccionar la obra creadora, pero no debe hacernos creer que con ella tenemos la comprehensión de toda la realidad, y muchos menos que adjudiquemos el sentido de todo lo real.

\section{Ver el mundo, el hombre y a Dios deSDe CRISto}

Una aportación importante de San Juan de Ávila es su mirada antropocéntrica, pero desde Cristo, expresión suprema del amor de Dios y culmen de la plenitud de lo humano. Con Él y en Él el hombre llegará a su plenitud. Desde Cristo hecho hombre y muerto en la cruz por amor, San Juan de Ávila mira al hombre y descubre en él toda su dignidad y potencialidad. La aportación más decisiva de San Juan de Ávila es la de mirar a Cristo y, con Él y desde Él, al hombre, a la creación y a Dios, porque Él es la expresión máxima de verdadera humanidad; con Él la creación llega a su plenitud, a «recapitular todas las cosas consigo», y en Él se nos manifiesta el auténtico rostro hermoso y tierno del Padre, sus entrañas de misericordia para este mundo.

El Santo Maestro no mira sólo la encarnación, sino también la muerte y resurrección. Es en la muerte en cruz, con su costado abierto donde se nos manifiestan las entrañas de misericordia del Padre, del mismo Hijo y también el amor del Espíritu que desde allí se nos derrama para penetrar, a manera de Pentecostés, en cada uno de los corazones de todos los habitantes de la tierra. Al encarnarse, Cristo le confiere al hombre una dignidad inigualable porque lo eleva a la categoría de hijo en el Hijo. Pero esto se ha llevado a efecto fundamentalmente

23. Audi, filia (II), 32, 1: I, 607-608.

24. Audi, filia (II), 31, 2: I, 607.

25. Audi, filia (II), 31, 3: I, 607. 
al morir Cristo por nosotros. Valemos ahora la misma sangre del Hijo de Dios. Nos ha puesto precio al pagar por nosotros su misma sangre derramada en la cruz. Se trata de la misma sangre del Hijo, del mismo Dios. Así nuestro precio está ya puesto: la sangre preciosísima del Hijo. Por eso, desde la cruz, el hombre adquiere el máximo valor que nunca se hubiera podido imaginar.

Así es que San Juan de Ávila ve el valor y dignidad de los hombres, de cada hombre, desde Cristo. Dios ve a los hombres también desde su amado Hijo. Primero porque nos dice el mismo Juan de Ávila que ya estaba pensando el Padre en el Verbo encarnado antes de la creación. Es decir, no quería crearnos sin tener en cuenta la imagen de su Hijo encarnado ya en su mente antes incluso de la creación del mundo, con lo que nos hizo a imagen del Hijo. Es decir, no quería hacernos lejos de Él, sino a imagen de su Hijo. Ya estaba Jesucristo destinado a su encarnación antes de nuestra creación. Su mirada a la creación se hacía desde la mirada de amor a su Hijo encarnado en la mente del Padre: «Y así como la primera operación en orden (no en tiempo) que el Padre tuvo en su eternidad fue engendrar a su Hijo igual a él, así la primera y principal obra de las que en tiempo se habían de hacer ordenó en su mente divina que el que por este nacimiento eterno fue Dios fuese otra vez engendrado de Santa María Virgen $»^{26}$.

Pero ahora también nos ve el Padre a través de los agujeros misericordiosos de las llagas de su Hijo entregado en la cruz por nuestra definitiva salvación. A través de sus llagas de amor y misericordia. Dios es el Padre lleno de ternura, que nos mira con amor desde su Hijo. También nos oye desde los gritos del Hijo, que ahora intercede ante el Padre por nosotros. El Padre nos identifica como hijos en el Hijo. Y como a su mismo Hijo nos trata. Por eso cuando le pedimos nos ve y nos oye en el Hijo, como si fuese su mismo Hijo el que se lo pide. Su Hijo habita y se ha unido a nosotros desde su encarnación y muerte de manera inefable, para lo cual no hay palabras que lo puedan describir, sino que somos un espíritu con Él, para el Padre ya no somos su Hijo y nosotros sino todos en su Hijo. Esto es un misterio de unidad y cercanía que es un gran misterio, pues el trascendente llegue a unirse con la pequeñez del hombre de esta forma sólo se puede comprender desde la fe profunda en el amor del Padre, del Hijo y en la acción del Espíritu, que es el que realiza esta unión admirable.

\section{DIOS ES EL CENTRO DEL HOMBRE}

Dios está en el más profundo centro del hombre. Pero cuando éste decide convertirse en el centro, se pone como medida de todas las cosas, y como piedra imán quiere atraer todo hacia sí. Esto hace que caiga en la soberbia, que para Juan de Ávila es el gran y principal pecado del hombre. En realidad, lo considera

26. Sermón 34, 25: III, 425-426. Cf. Ibid. 34, 23-27: III, 425-426; J. DíAz LoRITE, Experiencia del amor de Dios, 213-218. 


\section{Juan de Ávila desde la sociedad y cultura actuales}

el pecado original, al creerse ya los primeros hombres superiores a Dios que los creó. En esto consistía no obedecer su voz. Porque Él ya no estaba en el centro de la vida, sino que el hombre había usurpado este lugar. Y esto conlleva una serie de errores en los que el ser humano está cayendo. Con lo cual, en vez de caminar hacia arriba, hacia un auténtico progreso y plenitud, cae en la esclavitud de su «yo» que lo precipita hacía sí mismo, buscando sólo su propio interés, lo que le apetece, el placer inmediato, sin grandes objetivos en el horizonte que le muevan hacia la libertad afirmada en profundos y sólidos ideales.

Entre estos objetivos que el hombre se ha marcado está el gusto por lo inmediato, incluso en lo religioso en el que la relación con Dios se puede no buscar por lo que Dios es en sí mismo, sino por lo que en un determinado momento le puede aportar de complacencia intimista o sentimiento espiritual. Para ello prevendrá San Juan de Ávila que lo hay que hacer es amar a Dios no tanto por lo que se saboree o no de Él, sino por puro amor hacia Él, aunque ningún otro beneficio nos reportase, pues ahí reside el verdadero amor.

EI Santo Maestro no sólo advierte del peligro de buscar por encima de todo la satisfacción o sentimentalismo espiritual y el de buscar como fin las apetencias de lo efímero, de lo pasajero como es el poder, el dinero, el lujo, el desenfreno, el hedonismo, etc., muy propios de aquella época en la que surgen los nuevos ricos después de la reconquista y del descubrimiento del Nuevo mundo, que basan la seguridad y el sentido de su vida en estos ideales terrenales.

Cuando se deja a Dios ser lo que verdaderamente es: el centro de nuestro ser; todo lo demás se recoloca y adquiere su sentido, siempre importante pero relativo en comparación con Aquél. Por eso dice: «[...] aprendamos de aquí en adelante a dar nuestros deseos a Dios. Y como una piedra va hacia lo bajo, $y$ un fuego a lo alto, y cada cosa a su lugar, así su corazón vaya a su centro con gran ligereza, que es Dios ${ }^{27}$.

Reconocer que Dios es nuestro centro y nuestro fundamento primero ${ }^{28}$, ayuda a no quedarnos en la vanidad de la vida, porque todo lo que tenemos se lo debemos a Dios, incluso la existencia diaria, ya que si su amor faltase sólo un momento dejaríamos de existir, y no sólo de nosotros, de todo lo que existe, también de lo material. "Y considerad a Dios, que es el ser de todo lo que es, y sin Él hay nada; y que es vida de todo lo que vive, y sin Él hay muerte; y fuerza de todo lo que algo puede, y sin Él hay flaqueza; y que es bien entero de todo lo bueno, sin el cual no se puede haber el más pequeño bien de los bienes. Y por esto dice la Escritura: Todas las gentes son delante de Dios como si no fuesen, y en nada y en vanidad son reputadas delante de Él (Is 40,17). Y en otra parte está escrito: El que piensa que es algo, como sea nada, él se engaña (Gál 6, 3)» ${ }^{29}$.

27. Carta 39, 66-69: IV, 206.

28. Cf. J. DÍAZ LoRITE, Experiencia del amor de Dios, 195-197.

29. Audi, filia (II), 64, 3: I, 673. 
En medio de una cultura como la actual, que mira sólo y exclusivamente la apariencia y la imagen, y donde el hombre, sintiéndose fragmentado interiormente, quiere huir de sí mismo para no tener que enfrentarse con su propio vacío existencial, producto de la sociedad que lo domina y en la que él también hace su aportación, San Juan de Ávila nos propone una mirada al interior para que con los ojos misericordiosos y de verdad que nos da Dios lleguemos a la verdad de nosotros mismos, y así vivamos la auténtica libertad, pues nos decía Nuestro Señor: «la verdad os hará libres» (Jn 8, 32).

Pero en este camino hacia el interior no piensa San Juan de Ávila en una mirada exclusivamente psicológica, lo que no quiere decir que la excluya totalmente, sino que parte y está siempre impregnada de la mirada de amor con que Dios nos ve. Dios, en su Espíritu, es el que nos conoce más que nosotros a nosotros mismos, y nos quiere iluminar en el camino hacia el interior para descubrir nuestra propia verdad, y llegando al fondo lo encontremos a Él que habita en nosotros. Hacerlo de otra manera nos acarrearía hasta incluso el peligro de disimular nuestra realidad, de confundirla con otras, de mezclarlas con algunas, o de enmascararla. Todo lo cual nos conduciría a vivir en un error permanente, y por tanto, y como consecuencia, no llegar a la verdad de nuestro ser, a la auténticas paz y gozo que no vienen sino desde la armonía que experimentamos desde lo más profundo del corazón.

Se trata de una mirada desde el amor de Dios, desde el amor con que nosotros mismos debemos mirarnos, pues somos sus criaturas. A veces somos demasiado crueles al mirarnos a nosotros interiormente; esto nos puede provocar mirar con la misma crueldad a las demás personas. San Juan de Ávila nos avisa también del error contrario, de entrar con todas las justificaciones posibles para no querer ver en nuestro interior la verdad más profunda, nuestra propia debilidad, flaqueza, pecado, nuestra nada en el fondo. Por eso advierte San Juan de Ávila: «[...] por el mucho amor que nos tenemos, no sabemos conocernos y reprehendernos con aquel verdadero juicio que requiere la verdad, debemos agradecerlo a la persona que nos reprehende; y también suplicar al Señor que nos reprehenda con amor, enviándonos su luz y verdad (Sal 42, 3)» ${ }^{30}$.

Por eso nos alienta a entrar sin miedo, pero sí con la humildad suficiente para ver todo lo que haya en nuestro corazón, hacer armonía en él desde el corazón del amor de Dios que nos lo contagia a nosotros, y desde ahí penetrar en la verdad de nosotros mismos. Único camino para la armonía y la realización existencial. Pues si somos rivales para nosotros mismos, ¿cómo podremos llevar una vida de paz, gozo y felicidad auténticas?

Pasos en este camino hacia el interior:

30. Audi, filia (II), 62, 4: I, 669. 


\section{Juan de Ávila desde la sociedad y cultura actuales}

\section{a) Entrar en nosotros mismos}

Acostumbrados a mirar al exterior San Juan de Ávila invita a hacer el necesario ejercicio de mirar a nuestro interior para descubrir la verdad de nosotros mismos: "Miraos a vos»" "mirad vuestro ser»32, "entrad dentro de vos misma»" En esta mirada desde el amor de Dios descubriremos nuestra verdad, verdad que consiste en ver por una parte, que lo positivo que tenemos viene de Dios y hay que valorarlo en tanto en cuanto es don de Él y no apropiárnoslo como si de ningún otro viniera. Poder llegar a reconocer esto viene sólo de tomar conciencia de nuestra nada, de nuestra poquedad y de nuestra condición de criatura. Por eso aconseja: «Sabed, pues, ahondar bien en el ser y fuerzas que tenéis y no paréis hasta llegar al fundamento primero» ${ }^{34} \mathrm{y}$ decid: «No tengo, Señor, que buscar fuera de mí, pues estáis vos más íntimo a mí que yo a mí mismo, y que he de pasar por mí para entrar en vos» ${ }^{35}$. Pero sólo aceptando que al entrar con nuestra nada es como podemos llegar a encontrarnos en nosotros con nuestro todo que es Dios. También en esta mirada desde el amor de Dios descubriremos nuestro pecado, lo que no se ajusta a la voluntad de Dios y lo sabremos reconocer desde la misericordia de Dios hacia él, lo que nos ayudará a cambiar y a crecer.

\section{b) Del no ser al ser, por amor de Dios}

Es importante en este camino hacia el interior considerar cómo nuestra existencia se la debemos a Dios. De ahí que nosotros podamos ser conscientes de que sin Él no somos nada. Antes de que Él nos crease no éramos nada, y gracias a su amor hemos venido a ser, hemos venido a la existencia. Esto nos hace ser realistas y vivir en la verdad. Le debemos la vida a Dios. No somos dueños ni señores de nuestra existencia. La tenemos gracias a su amor y generosidad para con nosotros. Esta consideración nos producirá, por una parte humildad, y por otra, agradecimiento por el de nuestra existencia.

San Juan de Ávila precisa que existimos porque Dios nos ama, y no al revés. Es su amor el que produce nuestra existencia, y nos crea porque nos ama y para amarnos. Así nos dice: «Habéis de pensar quién érades antes que Dios os criase, y hallaréis ser un abismo de nada, y privación de todos los bienes. Estaos un buen rato sintiendo este no ser, hasta que veáis y palpéis vuestra nada y no ser. Y después considerad cómo aquella poderosa y dulce mano de Dios os sacó de aquel abismo profundo, y os puso en el número de sus criaturas, dándoos verdadero y real ser. Y miraos a vos, no como hechura vuestra, sino como a una

31. Audi, filia (II), 64, 2: I, 672.

32. Ibid.

33. Audi, filia (II), 64, 3: I, 673.

34. Ibid.

35. Audi, filia (II), 64, 4: I, 673. 
dádiva, de la cual Dios hizo merced a vos. Y por tan ajeno a vuestras fuerzas mirad a vuestro ser, como miráis al ajeno, creyendo que tampoco os podistes vos criar a vos, como criar a otro. Tampoco podíades salir de aquellas tinieblas del no ser, como los que quedaron en ellas. Y tenéis por igual de vuestra parte a las cosas que no son, atribuyendo a Dios la ventaja que les lleváis» ${ }^{36}$.

\section{UNA FE QUE MIRA MÁS ALLÁ DE LO TANGIBLE, SUPERFLUO, INMEDIATO, ECONÓMICO}

En el mundo en el que vive San Juan de Ávila se desarrolla un nuevo estilo de vida, especialmente el de los nuevos ricos, que con el descubrimiento de América, con los territorios reconquistados a los árabes en la península, el auge del comercio y las cargas hacia las clases menos pudientes, hace que la sociedad se vaya fragmentando todavía más en clases opulentas junto a otras paupérrimas: campesinos cargados de impuestos, mendigos, viudas, huérfanos, muchos de ellos a consecuencia de las guerras, etc.

Los acontecimientos comienzan a sucederse con más rapidez, y la vida se comienza a vivir más antropocéntricamente, es decir, más desde el hombre, y no desde el estatismo de Dios, en el que no hay tiempo. Ya no es el sol el que da vueltas alrededor de la tierra, sino la tierra alrededor del sol. La tierra se mueve. La vivencia del tiempo se hace más rápida, pues estamos en movimiento. Las cosas se suceden a más velocidad y así los cambios en la sociedad y en la naturaleza. El hombre se hace la medida de las cosas, también del tiempo. La percepción de la realidad es más fugaz, más superflua, más caduca. Todo esto facilita que se mire más lo superficial haciendo que el corazón, sobre todo de los pudientes y de los que marcan el ritmo social, se desplace hacia las banalidades, los lujos, las cosas efímeras, etc.; todo en función del placer inmediato que reportan, de los intereses de cada momento, más bien pasajeros y no eternos, pues el sentido de eternidad que antes estaba en Dios, ahora comienza a ponerse sólo en lo caduco. Ahora la atención se focaliza hacia la naturaleza, que comienza a ser inspiración para pintores, escultores, etc., y de igual forma el hombre. Toda esta realidad no es negativa en sí misma sino cuando se convierte en absoluta.

San Juan de Ávila advierte sobre esta forma de entender la vida, y va contra los lujos, el desenfreno, la ostentación, etc. Un claro ejemplo de esto lo vemos en la amonestación a muchos cristianos de Granada a no seguir dando mal ejemplo a los árabes de estas malas costumbres: "Es verdad que a esos moros que están en Granada no les lucimos, como dice Sant Pablo, porque somos nosotros tan malos, tan amigos de hacienda, tan dados a deshonestidades, tan vanos, tan glotones, que aun somos peores que ellos (cf. 1 Cor 6, 9-10) [...] Quiere decir

36. Audi, filia (II), 64, 2: I, 672. 
que ver que, siendo nosotros hijos de Cristo por adopción, hay entre nosotros tantas carnalidades, tantos robos, tantos logros, tanta vanidad, tantos trajes y locuras, que los que dicen que siguen a Cristo crucificado, tanto lo contradigan en las costumbres ${ }^{\prime 37}$. Dada esta situación, el Santo Maestro insiste en no utilizar la procesión del Corpus de Granada para la ostentación de lujos, trajes, etc. ${ }^{38}$

No es de extrañar que el Santo Maestro pueda ayudar al proceso de discernimiento y conversión de san Francisco de Borja, quien tomó definitiva conciencia de la poquedad de las cosas del mundo al contemplar el cadáver de la emperatriz Isabe| $\left.\right|^{39}$. También aconseja vivamente que la ida a América no se haga movidos por el afán de riquezas o por la ambición, pues el poder, la ostentación y el dinero no pueden ser los ideales del hombre.

El Santo Maestro nos dice que en muchas ocasiones nuestra oración no es escuchada porque en ella habitan sólo las cosas materiales, no dejando a las que realmente hay que pedir a Dios que son las espirituales. Por eso la oración hay que hacerla bajo la luz del Espíritu que ora en nosotros y nos hace gritar «AAbba, Padre!» (Gál 4, 6) ${ }^{40}$.

San Juan de Ávila es un ejemplo de persona dependiente sólo de las manos de Dios, y no de las cosas de este mundo. Es un verdadero mendigo de Dios, como él mismo también definió a San Francisco de Asís ${ }^{41}$. Siguiendo como éste los pasos de Cristo, colgado sólo de la voluntad de Dios hasta la cruz, San Juan de Ávila vivió siempre una vida pobre y austera, considerándose en tan poca cosa que renunció por humildad a varias canonjías y a los obispados de Segovia y de Granada, pues creía que no era digno de tanto honor. Gran lección para el hombre competitivo de hoy cuyas aspiraciones están con frecuencia situadas en el poder y en todo lo que éste lleva consigo.

El Santo Maestro promueve una vida de austeridad que mira a lo eterno, a confiar sólo en Dios, en cuyo amor lo pasajero es insignificante y en comparación con Él todos los afanes de este mundo son sólo paja. La razón de todo esto es que, como dijimos, el hombre está destinado a Dios, y mientras no lo alcance no conseguirá su plenitud aunque tenga todos los bienes de este mundo. Dios se da sí mismo a aquel que lo ama, y ésta es la mayor riqueza que el hombre puede alcanzar: "La tercera merced que Dios hace al que le ama es mayor que ningún entendimiento humano puede decir, y es que el mismo Dios se da a sí mismo a aquel que le ama [...] Y en este punto que le ama, viene a él, como águila herida, a hacerle bienaventurado y lleno de todas las riquezas que Dios le puede dar y él puede alcanzar. ¡Bienaventurado, hermanos, el corazón donde

37. Lecciones sobre 1 San Juan (I), 4 $4^{\text {a }}$ 164-179: II, 130.

38. Cf. J. Esquerda BIFET, «Corpus Christi», en Diccionario de San Juan de Ávila, Burgos 1999, 241-242. Cf. ID., «Vestidos», 936-938; ID., «Riquezas», 809-811.

39. Cf. ID., "Francisco de Borja», 433-434.

40. Cf. Lecciones sobre 1 San Juan (I), 17, 246-255: II, 266.

41. Cf. Sermón 78: III, 1044-1062. 
Dios por amor se aposenta! $»^{42}$. Por eso, aconseja dejar todo lo que nos estorbe para ganar a Cristo, porque en Él están todos los bienes a los que el hombre puede aspirar para llegar a su plenitud: "Cierto, quien de tu amor se mantiene no morirá de hambre, no sentirá desnudez, no echará de menos cuanto en el mundo hay, porque, poseyendo a Dios por el amor, no le falta cosa que buena sea [...] Quiero decir, cómo los que aman a Dios en las injurias no sienten injurias; en el hambre están hartos; deshechados del mundo, no se afligen; tentados del fuego carnal, no se queman; hollados, están en pie; parecen pobres, y están ricos; feos, y son hermosos; extranjeros, y son ciudadanos; acá no conocidos, y muy familiares a Dios. Todo esto y más hace el noble amor de Jesucristo en el corazón donde se aposenta [...] Demos, pues, nuestro todo, que es chico todo, por el gran todo, que es Dios. Tengamos todas las cosas por estiércol por ganar la perla preciosa que es Cristo» ${ }^{43}$.

\section{UNA FE QUE PROMUEVE EL VALOR DE LA PERSONA}

Para Juan de Ávila la persona tiene valor en sí misma, un valor garantizado y otorgado por el mismo Dios. No le viene dado por la convención o acuerdo de ningún organismo internacional o colectivo. Si fuera así, el valor de la persona estaría a merced de los intereses de unos cuantos que por circunstancias coyunturales se los otorgasen en mayor o menor medida, pudiendo ampliarlos o-lo más probable- disminuirlos en virtud de intereses partidistas.

El valor de la persona, de cada persona, reside en su mismo ser, por su condición de existir, pues desde su nacimiento goza de una dignidad superior al resto de los seres. Pero aún va más allá, el Santo Maestro fundamenta la dignidad de toda persona en su condición de hijo de Dios, amado por Él desde toda la eternidad. En virtud de este amor de Dios al hombre no sólo existe, sino que se mantiene en la existencia, y no solamente como criatura sino como hijo de Dios, que es la más alta distinción y honor a la que pudiéramos llegar a aspirar, participando por tanto de su mismo amor y condición divina en cuanto unidos a su Hijo Jesucristo. Por eso dice: "Señor, ¿participan como criados, como parientes, como hijos o como esposa? A ser así, mucho es [...] No se ha contentado tu misericordia con que gocemos de tu Hijo como parientes, criados, hermanos, hijos y esposa, que todo esto nos ha concedido; mas, sobrepujando unas misericordias con otras mayores, nos ha levantado a tanta dignidad, que seamos hechos cuerpo de Él, una misma persona con Él y que el bien que Él influye lo influya en sus miembros y, para decirlo en una palabra, Io influya en sí mesmo, pues cabeza y cuerpo una misma persona son $»^{44}$.

42. Sermón 23, 10: III, 282.

43. Carta 64, 41-62: IV, 285-286.

44. Sermón 53, 13: III, 691. 
Para San Juan de Ávila, como para Santo Tomás y para San Buenaventura, el ser y el seguir siendo del hombre no son dos acciones diferentes de Dios, sino dos momentos distintos de la misma acción creadora, ya que la continuación en el existir es continuación de su amor, que fue el origen de su ser. Dios se convierte así en el garante del valor permanente de cada persona, no dependiendo su dignidad de ningún acuerdo de instancias humanas.

Esta relación de amor, de dependencia amorosa de Dios, que es nuestro fundamento y garante de nuestra dignidad, lejos de anular la autonomía propia del hombre, la potencia. El hombre posee su propia libertad y autonomía, aunque su ser y su virtud de obrar la tienen no de sí, sino de Dios. La acción de Dios no es la de hacer en lugar del hombre, ni la de utilizarlo como una marioneta, con lo que anularía su acción y libertad, sino la de concederle, la virtud para obrar, es decir la capacidad permanente para obrar en libertad ${ }^{45}$. Una libertad de la que el mismo Dios es garante, pues ayuda al hombre a no ser esclavo ni siquiera de sí mismo. A veces, el ser humano, ofuscado por el pecado, puede ser esclavo de su soberbia y todo lo que ésta conlleva. No llegando, si en ésta cae, a su propia realización personal, que es en lo que consistiría el objetivo de la verdadera libertad. Dios en su amor es el garante de esta plena libertad del hombre, pues liberando al hombre, incluso de sus mismas ataduras, ayuda y ofrece su fuerza para que el hombre desarrolle la capacidad otorgada por Dios para llegar a su realización plena.

UNA FE QUE PROMUEVE EL AMOR AL PRÓJIMO

La fe en Dios que vive y predica san Juan de Ávila es una fe viva, es decir, una fe que ama a Dios y por tanto al prójimo. Dios se convierte así en la fuente verdadera del amor al prójimo. Por eso, quien vive de este amor de Dios se ve envuelto irremediablemente en el amor comprometido al prójimo. Desde este punto de vista, San Juan de Ávila predica una ética, pero sustentada en Dios, que es el que potencia, garantiza y le da más empuje de amor comprometido. Al prójimo no se le ve ya sólo como semejante, ni sólo como criatura de Dios, ni siquiera como hermano, sino como al mismo Cristo que habita en él, porque inflamados del amor de Dios ahora amamos con su mismo amor, pues Dios es Amor. Por eso dice: «Entonces tiene la ánima la condición de Dios, del cual dice el mesmo San Juan: Deus caritas est (1 Jn 4, 8) ${ }^{46}$. Además, hay que atender a las obras porque si no "faltamos en el amor de Aquel que dijo: Lo que a uno de estos chiquitos míos hicistes, a mí me lo hicistes (Mt 25, 40) $»^{47}$. Desde

45. Cf. Plática 3, 19: I, 824; J. L. RuIz dE LA PEÑA, El don de Dios. Antropología teológica especial, Santander 1991, 358 y nota 43.

46. Lecciones sobre 1 San Juan (II), 21: II, 437.

47. Carta 85(2), 79-80: IV, 357. 
esta concepción, los demás hombres adquieren un status no dado por la persona, que reconoce en ellos también a otros iguales en dignidad, sino una categoría mucho más alta: son rostros vivos de Cristo, con quien Él se ha identificado en su encarnación. Pero aún más, esta identificación con Cristo se produce especialmente con aquellos más desvalidos, más sencillos, más necesitados. Por lo cual todos los hombres, y especialmente los más pobres e indefensos deben ser los destinatarios primeros de nuestro necesario amor. En ellos está Dios. Esta es la razón principal de nuestro amor al prójimo, que lejos de quitar el valor por lo que cada ser humano significa, lo que hace es potenciarlo aún más. Al amar al prójimo estamos glorificando al mismo Dios. El Santo Maestro afirma no sólo que «si al prójimo amáis por Dios a Dios amáis» "48, sino que también: «Si esa compasión al prójimo es verdadera, no se llama amor del prójimo, sino amor de Dios, porque se hace por Dios» ${ }^{49}$, lo que pasa es que para que ese amor sea bueno, "ha de descender del amor de Dios» ${ }^{50}$. La importancia que le da al amor al prójimo es tanta, que aunque los sermonarios ${ }^{51}$ pongan muchas señales para ver si uno está en gracia o no, él, siguiendo a San Juan, pone solamente una: si amamos a nuestros hermanos ${ }^{52}$. Por tanto San Juan de Ávila fundamenta el amor al prójimo en unas raíces mucho más profundas que en la mera y, por otra parte, siempre inexcusable solidaridad con los demás, o con en el solo respeto, o incluso con el necesario amor que tenemos que tener a los otros, sino que va mucho más allá. El mismo amor humano tiene unas raíces divinas, y por consiguiente viene sustentado, y entonces, exigido con mucha más hondura, por el mismo Dios, y por nuestra misma condición de criaturas e hijos de ese Dios. De manera que si no amamos, nos dice que no sólo no sentiremos paz sino que encontraremos a Dios seco con nosotros: "Hallaréis a Dios desabrido, si el prójimo os halla así a vos» ${ }^{53}$. De esta manera, no sólo el amor al prójimo es señal de estar en gracia de Dios, sino que se convierte también en condición de tener el gusto de la gracia, que es lo que venimos llamando la experiencia de la gracia. Y esto es así porque aquí también se cumplirá la sentencia, que «con la medida que midiéredes os ha Él de medir (Mt 7, 2). Pues no seáis vos corto, porque Dios no lo sea con vos» ${ }^{54}$. Por eso insiste: «Ni piense nadie que le medirá Cristo con otra medida

48. Lecciones sobre 1 San Juan (I), 24, 252: II, 337.

49. Lecciones sobre 1 San Juan (I), 23, 167-169: II, 322.

50. Sermón 25, 1: III, 298.

51. Cf. F. Rıco, Predicación y literatura en la España medieval, Cádiz 1977.

52. «Ponen los sermonarios tantas señales de gracia y de estar en caridad. Dios, por San Juan, puso ésta diciendo: Nosotros sabemos que somos trasladados de la muerte a la vida, porque amamos a nuestros hermanos», cf. Lecciones sobre 1 San Juan [II], 21: II, 437.

53. Carta 63, 73-74: IV, 282.

54. Carta 63, 75-76: IV, 282. «Y de esta manera le será nuestro Señor blando y piadoso, según Él lo ha dicho, que con la medida que midiéremos seremos medidos (cf. Mt 7, 2)», cf. Carta 110, 48-50: IV, 430. 
que con la que él a su prójimo mide [...] porque sembrar espinas en el prójimo y querer coger de Dios higos (cf. Lc 6, 44), no es razón» ${ }^{55}$.

El amor al prójimo nos lleva a ponernos en lugar del otro, a sentir con el otro, a estar alegres cuando el otro se alegra y entristecernos cuando se entristece. Es la verdadera compasión y la verdadera unión de corazones lo que el amor produce. En realidad, este amor supone salir de nosotros mismos para entrar en el otro, en su gozo, o en su pena, queriendo siempre su bien por encima de todo, lo mismo que una madre sólo encuentra su alegría en el bien del hijo: «Como cuando una madre quiere mucho [a] su hijo, que anda su vida colgada de la del hijo, y si salud quiere es por gozar de la del hijo, no tiene más alegría de la que tiene su hijo, no más contentamiento del que tiene su hijo» ${ }^{56}$.

Esta compasión, este sentir con el otro, lo presenta perfectamente el Santo Maestro al explicar el texto de Gálatas 2, 20, y tomando pie del pasaje de Pablo en la carta a los Tesalonicenses, donde dice: «Ahora sí que vivimos, pues permanecéis firmes en el Señor ${ }^{57}$, describe el verdadero amor al prójimo como el mismo Pablo trataba a los demás: «Mirad, no me preguntéis cómo estoy, sino mirad qué tales estáis vosotros: si estáis tristes, yo estoy triste; si estáis en pie, bueno estoy yo; si estáis caído[s], malaventurado de mí» ${ }^{58}$. Y continúa poniendo en boca de Pablo: «Estoy como la sombra con el cuerpo, que, dondequiera que va el cuerpo, va allá la sombra; mi alegría depende de la vuestra; mi descanso está colgado del vuestro; no tengo más vida de la que vosotros tenéis» ${ }^{59}$. Así, del estado del otro también depende nuestra paz y sosiego, o nuestro sufrimiento y tristeza.

En nuestra salida hacia el prójimo hay que tener en cuenta a toda la persona, tanto sus necesidades físicas como espirituales. Porque el amor abarca al ser entero. Así nos dice: «Mas no os olvidéis del prójimo, al cual también habéis de curar: cuerpo, por limosna, y ánima, por buen ejemplo y consejo» ${ }^{60}$. De esta forma, San Juan de Ávila coloca al hombre en su realidad integral, y nunca separada, cuerpo y alma, y a ella hay que atender y amar. Ambas dimensiones van incluidas en la persona y a ambas, sin excluir ninguna, hay que amar y acercarse para atenderlas debidamente. No se puede sólo pensar en una de ellas: sólo en las materiales o sólo en las espirituales, sino integralmente. San Juan de Ávila es el primero que lo ha vivido. Su acción ha sido la de atender a las personas, especialmente a los enfermos, huérfanos, muertos de hambre, viudas, campesinos, etc. en sus realidades más básicas: salud, comida, alojamiento, etc. pero también a éstos les ha ayudado en sus necesidades más humanas y espirituales: escucha, consejo, aliento en la fe, formación humana a través de colegios

55. Carta 12, 150-156: IV, 91.

56. Sermón 49, 8: III, 638.

57. 1 Tes 3, 8, según se cita en el Sermón 49, 8: III, 638.

58. Sermón 49, 8: III, 638.

59. Sermón 49, 8: III, 638.

60. Sermón 22, 35: III, 278. 
como veremos y formación espiritual. A muchos hasta en una dirección más profunda y necesaria como es la dirección espiritual personalizada llevando a los hombres a lo que verdaderamente los plenifica: Dios.

San Juan de Ávila aporta también una buena aclaración sobre la necesaria respuesta a la pregunta "¿Quién es mi prójimo?», indicando claramente que el prójimo no es aquél a lo que solemos denominar que está próximo, sino al que tiene necesidad de mí, y esto estando cerca o lejos, y hasta independientemente de su bondad o no, de su merecimiento o no de mis atenciones. Esto en realidad era lo que hacía Jesús, al dar su amor con total gratuidad y no por los merecimientos de sus destinatarios. Es más, más se volcaba con aquellos que menos lo merecían: pecadores, publicanos, prostitutas, para que así fuese manifestado con más claridad el amor gratuito de Dios. Esto lo ha vivido y predicado San Juan de Ávila de forma ejemplar al aclarar que todos deben ser destinatarios de nuestro amor, los de nuestra comunidad y los que no pertenecen a ella, los buenos y también los que no lo son, los que participan de nuestra fe y los que no. De manera que «todo hombre que yo pueda aprovechar o recebir de él provecho en acto o en potencia, aquel es mi prójimo» ${ }^{61}$. Al indicar en acto o en potencia, introduce San Juan de Ávila un concepto amplísimo de prójimo donde todos caben sin excepción. Y hasta llega a decir que prójimo son todos los hombres, pues todos son en potencia herederos de la eterna bienaventuranza: «Todo aquel que puede ser particionero en la bienaventuranza con nosotros, como todos los teólogos dicen, todo el tal es nuestro prójimo»"62. De manera que así, con toda razón puede especificar que «el moro, el judío, el hereje, el alarbe ${ }^{63}$ es nuestro prójimo; porque le podemos hacer bien y él a nosotros y porque puede convertirse y gozar de Dios con nosotros» ${ }^{64}$.

\section{UNA FE QUE CREA COMUNIÓN}

La sociedad actual vive en contradicción pues mientras presenta el valor de lo comunitario y desarrolla medios de intercomunicación como es Internet en el que la relación se puede hacer en tiempo real con cualquier habitante de la tierra, el hombre, sin embargo, es cada vez más individualista, está más ensimismado en su propio yo, y hasta físicamente se retira de los lugares de comunicación tradicionales: comida en familia, contacto con otros, pero más virtuales que físicos, etc. sin embargo, no podemos olvidarlo, el hombre es un ser social por naturaleza, es un ser comunitario, y en la vivencia de ello se juega su realización personal y colectiva. San Juan de Ávila, desde la comunión con el Dios

61. Lecciones sobre 1 San Juan (I), 21, 62-63: II, 297.

62. Sermón 22, 13: III, 269. Cf. StO. TOMÁS DE AQUINO, STh II-II q.25 a.12.

63. Se refiere al árabe.

64. Sermón 22, 13: III, 269. 
trinitario que experimenta y predica, también se convierte en un hombre de comunión que contagia comunión y que crea comunión sobre todo en torno a Jesús y en Él con los demás hombres. Su ayuda al acercamiento de Dios a los hombres y de éstos a Dios produce comunión allí por donde pasa. El Santo Maestro es el hombre de la comunión y de la fraternidad. Todo ello basado en la conciencia que tenemos de ser hijos de Dios, de que formamos parte de su familia. De manera que llega a decir que no podemos llamar a Dios Padre si no estamos dispuestos a llamarlo Padre nuestro.

Por eso llamarle Padre nuestro es tan importante que quien no acepta la fraternidad está rechazando al mismo Padre Dios: «Decimos a Dios Padre nuestro, luego todos somos hermanos. Quien no quiere el nuestro, no quiere a Dios por Padre. Siendo como somos hijos de Dios, somos todos hermanos» ${ }^{65}$.

Para San Juan de Ávila, por tanto, la fraternidad no funda nuestra filiación, sino a la inversa, ya que es la realidad de nuestra filiación adoptiva por la gracia de Dios la que hace que seamos todos hermanos unos de otros ${ }^{66}$. Pero por otra parte, para el Santo Maestro la verdadera filiación lleva aparejada necesariamente la fraternidad ${ }^{67}$. Esto hace que dicha fraternidad tenga raíces mucho más profundas y eternas.

Como a Jesús, al que nunca lo vemos solo excepto para orar en determinados y necesarios momentos, san Juan de Ávila tampoco es un hombre solitario. También él necesita su tiempo a solas para orar, para el estudio personal y escribir las cartas a los que se dirigen a él, o para preparar los sermones, etc., pero en su vida diaria lo vemos siempre rodeado de hermanos sacerdotes, religiosos, laicos, etc. creando fraternidad entre todos. Ya siendo joven sacerdote lo vemos compartiendo vida y misión en Sevilla mientras espera el ansiado y nunca logrado embarque hacia América con el sacerdote Fernando de Contreras y otros. Com-

65. Lecciones sobre 1 San Juan (I), 23, 404-406: II, 329. «En la primitiva Iglesia llamábanse los cristianos hermanos. Dice San Pablo: Si is, qui frater nominatur, inter vos est fornicator, aut avarus, aut idolis serviens, aut maledicus, aut ebriosus, aut rapax, cum eiusmodi nec cibum sumere (1 Cor 5, 11). El Señor nos dijo: Omnes vos fratres estis (Mt 23, 8). Nuestro Padre, Dios; nosotros, hermanos todos. Si hay sentimiento de esta verdad, meted la mano en el pecho y juzgadlo vosotros. Dirá el otro loco: 'No me digáis que es mi hermano; yo de buen linaje y él de malo; yo honrado y él de ruin casta: tiraldo allá, que ni es mi pariente ni lo quiero'. Llamábanse en aquel tiempo hermanos. Llegad a llamar agora 'hermano'; deciros han no sé qué. El día del juicio se demandará cuenta de esto y dará Dios sentencia contra los que no tienen amor aquí con sus prójimos», cf. Lecciones sobre 1 San Juan [I], 9, 156-167: II, 181.

66. Melquíades Andrés, refiriéndose al pensamiento de San Juan de Ávila dice: «La fraternidad humana no se basa de modo ineludible en fundamentos románticos, como los de Beethoven y de Schiller, cuando éste último canta: Alle Menschen werden Brüder [Todos los hombres llegarán a ser hermanos], ni en la ideología de la pura solidaridad humana, ni en cualquier otro sistema similar. Tampoco proviene de impulsos de la carne o de la sangre sino de Dios. La fe en su paternidad universal ofrece solidez indestructible a la unidad entre los hombres», cf. M. ANDRÉs MARTín, San Juan de Ávila, maestro de espiritualidad, 94.

67. "La garantía de esta actitud filial es el amor a todos los hermanos», cf. J. ESQUERDA BIFET, Introducción a la doctrina de San Juan de Ávila, Madrid 2000, 391. 
parten vida y tareas pastorales. También en Écija vive en casa de Tello de Aguilar y su esposa Doña Leonor de Inestrosa, lugar de encuentro, de formación, oración y fraternidad de clérigos y laicos. Allí vive una vida de comunión con algunos discípulos que se le van agregando en vida y misión tanto en Écija como en localidades cercanas: Alcalá de Guadaira, Lebrija, Jerez, Palma, Utrera, etc. ${ }^{68}$

También lo vemos en fraternidad en Córdoba, en el convictorio de Granada donde hasta incluso come en comunidad, en Baeza, y posteriormente en su retiro de Montilla. También ha potenciado la formación de convictorios para que los sacerdotes vivan en comunidad, y la creación de seminarios para que los futuros sacerdotes se vayan formando al presbiterado desde una vida común. La creación de numerosos colegios a través de toda Andalucía, en donde en muchos se comparte comida y estancia, es también una contribución de San Juan de Ávila a la necesaria vida comunitaria para poder crecer como personas, como seminaristas y como sacerdotes. Contribución ésta importante cuando el hombre de hoy, cada vez más individualista, busca espacios aislados como aquellos en los que cree encontrar su máxima realización, sin darse cuenta de que el hombre es por naturaleza un ser social necesitado de los demás, incluso de la cercanía física y comunitaria, respetando, como también san Juan de Ávila, los espacios privados de intimidad tanto interna como externa.

Pero esta necesaria vida comunitaria viene exigida por otra de más calado, que es la de la comunión afectiva y de amor en la que es necesario vivir en todo momento, cada uno en las circunstancias y estados de vida en las que ha sido llamado. Es la comunión de los hijos de Dios que se ha que potenciar y garantizar, y para ello es decisiva la comunión con el Dios trinitario, que es comunión y fuente de comunión. Aquella no es sino expresión de ésta más profunda y fundamental. La comunión en Dios crea comunión

Pero la comunión que predica San Juan de Ávila, y que vive, hasta en forma física con algunos discípulos, es más extensa. Predicando a Cristo y uniendo a la gente a Él extiende vínculos de comunión por allí por donde pasa. Su predicación crea comunión de discípulos a los que no les une una determinada regla de vida establecida según unos cánones, pero sí les hace establecer y sentirse parte de un proyecto comunitario de amor y de misión. También organiza grupos de encuentro y oración en torno a la Palabra de Dios que crean vínculos de comunión entre los asiduos participantes. Y en general, fomenta la comunión entre las personas desde su predicación evangélica desde los púlpitos y plazas públicas. El caso más llamativo, al que también nos referiremos más adelante, es el de la comunión que es capaz de crear entre los habitantes de Baeza, divididos y enfrentados en largas y duraderas guerras internas, y cuya palabra evangélica es capaz de apaciguar y acercar los corazones divididos.

68. Cf. J. Esquerda BifET, «Écija», en Diccionario de San Juan de Ávila, 319-320. 
UNA FE QUE MIRA A LA COLECTIVIDAD: A LA ALDEA GLOBAL EN LA QUE EL MUNDO COMIENZA A CONVERTIRSE

En la época de San Juan de Ávila el mundo comienza a ensancharse por el oeste y por el este, hasta llegar a la aldea global en la que hoy se ha convertido. Ya se están conquistando los territorios de América. También por el Oriente con las rutas abiertas por los portugueses en el camino de la seda y con la evangelización de San Francisco Javier. También tiene lugar la penetración en África. Todos estos horizontes, en muchas ocasiones manchadas de ambición y de injusticias, van a ayudar por otra parte a tomar conciencia paulatina de que el mundo es algo más grande que el mero eurocentrismo, si bien éste quiera imponer su idea de civilización a los demás, no reconociendo en parte su propia idiosincrasia. La mirada de San Juan de Ávila se va también ensanchando y ayuda a otros a verlo así desde la anchura que el amor de Dios creador de todo y de todos da. Su decisión antes de ordenarse de pasar a las misiones en Méjico acompañando al nuevo obispo de Tlaxcala era ya un indicio de la mirada abierta y universal de Juan de Ávila. Aunque vivía en España tenía ya los ojos fijos en ese Nuevo Mundo, todavía no descubierto del todo. Y aunque por obediencia se quedó en España su espíritu siempre estuvo abierto a toda la tierra y no sólo al Nuevo Mundo. El Santo Maestro también está al corriente de la misión de San Francisco Javier, de la que le llegan noticias por discípulos suyos que le informan puntualmente de esta evangelización, además de las referencias que va teniendo de los compañeros jesuitas de San Francisco Javier, jesuitas a los que el P. Ávila aprecia y estima en gran medida hasta su muerte. También la situación de la corriente de Lutero como protesta ante la Iglesia preocupa a San Juan de Ávila que desea una verdadera Reforma de la Iglesia, pero sin que se tenga que dar el paso de abandonarla. Así es que la mirada de San Juan de Ávila es amplia, tiene en cuenta a toda la humanidad. Así dice en una carta a un discípulo: « $i Q u i e ́ n$ pudiese tener mil millones de lenguas para pregonar por todas partes quién es Jesucristo! $\nu^{69}$. No es extraño que muchos de sus discípulos, inflamados de este espíritu evangelizador universal, se hagan misioneros en otros continentes. Al mismo San Juan de Ávila podemos considerarlo como un verdadero misionero universal. El mismo san Juan de Ávila, es un misionero universal ${ }^{70}$. Su radio de acción no se quedó en la ancha Andalucía, de la que es considerado Apóstol, sino que como decimos, en su corazón cabe toda la humanidad, porque está convencido de que el amor de Dios, manifestado en Cristo, es para todos y debe llegar a todos, como el mismo Cristo indicó a los Apóstoles: «Mandó a sus siervos, que fueron los apóstoles, ir unos a Oriente, otros a Occidente, etc. ${ }^{71}$. El beneficio de Cristo no

69. Carta 207, 14-16: IV, 673.

70. Cf. J. Esquerda BIFET, «Universalismo», en Diccionario de San Juan de Ávila, 929-932.

71. Sermón 24, 22: III, 291. 
sólo se extiende a todos los hombres de la tierra de una generación sino de todas las generaciones, por ello dice de él: "También se le dio a aquel tan nuevo hombre que fuese Padre universal y Cabeza de todos los hombres, para que en todos ellos, como cabeza espiritual, influyese su virtud (cf. Col 1, 18; 2, 9). De manera que Él, en cuanto Dios, es igual al Eterno Padre, y, en cuanto hombre, es Cabeza de todos los hombres [...] Esta gracia también es infinita, porque es para toda la generación humana, que no tiene número de personas determinado, sino puede, en cuanto es de su parte, multiplicarse en infinito» ${ }^{72}$.

UNA FE QUE HACE VIVIR CON COHERENCIA LOS VALORES QUE SE PREDICAN

Desde la fe en Jesús, San Juan de Ávila vive un estilo de vida con una serie de valores que sirven de luz y ejemplo para todos aquellos que lo ven y oyen, y que bien merecen ser tenidos en cuenta en la sociedad actual. Una sociedad que es capaz de vislumbrar una serie de valores éticos necesarios para vivir una vida feliz, pero que no ve referentes que los vivan realmente. Algunos de estos valores ya los hemos ido indicando a lo largo de estas páginas. Pero lo que ayuda a que esos valores puedan ser imitados es la coherencia de vida de quienes los presentan.

Pues bien, en San Juan de Ávila destaca ante todo su coherencia de vida. En realidad, creo que es el secreto del fruto de su acción evangelizadora, que le hace perdurar en el tiempo a lo largo de los siglos. El Santo Maestro habla, como el mismo Cristo, con autoridad, porque vive lo que dice. Su amor es un amor entregado, su ternura hacia los demás es una realidad, se pone en el lugar del otro. Lo que dice, incluso cuando corrige errores de la persona o de la sociedad, lo hace desde el amor y la caridad. La austeridad que predica para los demás él es el primero que la vive. Los consejos que da a sus discípulos sobre la importancia de la oración, de la paciencia, del perdón a los enemigos, la confianza en Dios en todas las circunstancias, hasta en las calumnias, es el primero que las lleva a la práctica. También es importante su paciencia a la hora de hacer frente al dolor en la enfermedad que él mismo padece, pues sobre todo a partir de los 50 años comenzó a tener grandes dolores de ijada, riñones, artritis, etc., que le tuvieron durante mucho tiempo a echa levanta, hasta su muerte en 1569. Él, desde el dolor confiado en el Señor sufriente en la cruz, sabe hasta incluso consolar a todos aquellos que sufren también la enfermedad y acuden a él buscando fuerzas para poder seguir adelante.

Sobre el amor entrañable a cada persona que tenía San Juan de Ávila nos dice su primer biógrafo: «No era suyo, sino de aquellos que lo habían menester» ${ }^{73}$.

72. Tratado del amor de Dios, 104-116: I, 955-956.

73. L. DE GRANADA, Vida del Padre Maestro Juan de Ávila y las partes que ha de tener un predicador del evangelio, en: ID., Obras completas, ed. A. Huerga, I, Madrid 1997, p.2 ${ }^{\mathrm{a}}$ c.3. 
También otros testimonios nos dicen que «a todos atendía con tanta caridad que a cada uno parecía 'que a nadie había hecho la merced y acogimiento que a él, según la afabilidad y buen modo con que lo hacía'» ${ }^{74}$.

También San Juan de Ávila es apreciado por sus sermones precisamente porque nacen del amor hacia los demás. Mucha gente acudía a oírlos expresamente porque predicaba San Juan de Ávila. Todos sus sermones nacen del amor y mueven al amor a Dios y al prójimo, y son hechos, no desde la mera grandilocuencia o con palabras deslumbrantes, sino desde un corazón lleno de amor a todos.

Su amor llega a pueblos enteros como es el caso de Utrera. A la villa le escribe una carta preciosa, la carta 86, en la que después de algunos desórdenes, les amonesta a vivir todos en paz y en armonía, tanto a los que gobiernan como a los súbditos.

Para el Apóstol de Andalucía el amor a los demás es el primer factor del éxito en la evangelización. Así se lo expresa al arzobispo de Granada: "Y tengo este medio por muy provechoso para los cristianos nuevos, los cuales, viendo buen ejemplo, que no buscan sino ánimas, se suelen convertir más que con palabras; pues aquella caridad dejóla Cristo encendida por Él en los corazones de sus ministros, y es tan fuerte que lo vence todo. Porque ¿quién se defenderá de un corazón que desea el bien, y bien eterno, a otro, y está aparejado a morir por él? Dícenme que lo que en la tierra del Japón más mueve a los gentiles a convertirse por de los de la Compañía es ver que han ido tantas leguas de tierra y mar a buscar la salvación de ellos, sin propio interés y con grandes trabajos y peligros de muerte ${ }^{75}$.

En una sociedad materialista como la actual cabe destacar la importancia de la vida austera de San Juan de Ávila que dejó todos sus bienes y repartió su herencia entre los pobres de su pueblo, viviendo ya a partir de entonces de la caridad, comiendo y vistiendo muy austeramente y no admitiendo vivir en palacios episcopales o de los señores de los reinos sino en hospitales y en casas pobres. En la respuesta que le da al P. Molina, que le insistía en que aceptase el sombrero nuevo que le regalaba la marquesa de Priego, pues el suyo andaba ya bastante desteñido, vemos lo que movía realmente el corazón de San Juan de Ávila en cuanto a la coherencia con la que actúa: «Cuando me suba al púlpito -le dijo- y reprehenda los vicios y exhorte a la pobreza y mortificación, y me vean a mí con buena sotana y buen sombrero, ¿qué dirán los oyentes? Así que, hijo mío, para los predicadores del Evangelio más fuerza tienen sus palabras cuando los que las oyen ven que van acompañadas con obras y que hazen lo

74. Proc. Jaén, decl. de H. Sebastián de Escabias, S. I., f. 1140v-1141r, en: J. L. MARTíneZ GIL, OH-M. GómEZ Ríos, CSSR, eds., Proceso de beatificación del Maestro Juan de Ávila, Madrid 2004, 677. Cf. Obras completas, vol. I (Introducción) 252-253.

75. Carta 178, 45-54: IV, 592. 
que dicen» ${ }^{76}$. Sus discípulos eran conocidos también por la austeridad y coherencia de vida con la que se comportaban. Este modo de actuar supo inculcarlo por ejemplo a todos aquellos que se formaban en Baeza. Por eso dice su segundo biógrafo refiriéndose a los clérigos que se formaban en la universidad de Baeza con el estilo de vida que inspiraba san Juan de Ávila, su fundador: «Un clérigo de Baeza se conoce en toda España en la modestia, moderación del traje, compostura y gravedad de costumbres $\rangle^{77}$.

El Apóstol de Andalucía denuncia al Concilio de Trento el lujo de muchos prelados y eclesiásticos. Así escribe en el segundo de los Memoriales a este Concilio: «El aparato de muchos prelados y eclesiásticos con tapicerías, vajillas, vestidos de criados y cosas semejantes es tal que puede competir en vanidad con los caballeros y señores temporales, mandando lo contrario los concilios y enseñándolo los santos, y haciendo mucho daño al pueblo con su mal ejemplo, que es causa de ser imitado, con grave daño de los imitadores. A una ciudad vino un obispo -continúa-, y quejábanse de él, diciendo que les había traído vestidos trajes de la corte, y les había hecho mucho mal a su ciudad» ${ }^{78}$.

Para el Apóstol de Andalucía la distinción por la dignidad sacerdotal significa distinción "en la humildad aun exterior, en vestidos y pompas»" ${ }^{79}$. En las «Advertencias» para el sínodo de Toledo detalla cómo aplicar las disposiciones de Trento sobre la pobreza de los prelados ${ }^{80}$. En las pláticas $6^{a}$ y $8^{a}$ y en la carta 177 también aborda la pobreza de los prelados y eclesiásticos a la luz de las disposiciones de Trento.

\section{UNA FE QUE PROMUEVE LA TRANSFORMACIÓN DE LA SOCIEDAD}

San Juan de Ávila no predica una doctrina aséptica que no tenga que ver con la realidad que se vive, sino que lo que pretende es que se pueda vivir la realidad del evangelio y que ésta realidad impregne y module todos los ámbitos de la vida eclesial y social de manera que todos estén inspirados en los valores del evangelio. En realidad, sueña con hacer posible que los valores del Reino se vayan viviendo en la tierra.

Escribe José Manuel Madruga Salvador: «El celo apostólico de Juan de Ávila, alimentado con un fuerte espíritu de oración, es un celo por la extensión del Reino de Dios, que le lleva a correrías apostólicas y a implementar catequesis, escuelas, servicios de caridad, nuevos métodos y caminos para llegar tanto a los sencillos aldeanos y niños como a los sacerdotes y a todo quien recurriera

76. Proceso de beatificación, 188.

77. L. MuÑOz, Vida y virtudes del venerable varón el P. Maestro Juan de Ávila, lib.1º, cap. 20.

78. Memorial segundo al concilio de Trento, 84: II, 604.

79. Ibid., n. 91: II, 611.

80. Cf. Advertencias al concilio de Toledo, I, ns.1-2, 8, 13: II, 645-655; Advertencias al concilio de Toledo, II, 10: II, 714. 


\section{Juan de Ávila desde la sociedad y cultura actuales}

a él. Las ansias de extender el Reino de Dios afloran con mucha frecuencia en los escritos de Juan de Ávila: 'Aunque ahora este Señor es conocido de pocos, mas siempre irá creciendo su reino, hasta que el fin del mundo reine en todos los hombres'» ${ }^{81}$.

Para San Juan de Ávila creer tiene como consecuencia vivir en los valores del Reino de Dios. Por eso, tras conocerle, los condes de Feria (don Pedro y doña Ana Ponce de León), cambiarán de vida, dejarán la carroza de plata que tenían y llevarán una vida de oración y austera, favoreciendo en sus territorios la creación de escuelas para la formación humana y religiosa de los niños y jóvenes, y ayudando a los campesinos que trabajaban para ellos.

Baeza no es la misma antes de llegar San Juan de Ávila, que después. Pues el testimonio y la predicación de San Juan de Ávila logre la pacificación de la ciudad, que no prosperaba por los enfrentamientos de las dos familias más influyentes, los Benavides y los Carvajales, enfrentamientos que llegaban a producir sangre en las calles de la aquella ciudad. Las gestiones de San Juan de Ávila contribuyeron a apaciguar la ciudad, y con esta paz vino el progreso económico y cultural de Baeza. También el religioso, pues la creación de la Universidad en 1542 bajo la dirección del Apóstol de Andalucía hizo que Baeza deslumbrara en vida religiosa. Atraído por este profundo ambiente religioso llegó años más tarde a Baeza San Juan de la Cruz, quien fue Rector del Colegio de San Basilio, y cuyos carmelitas acudían a las clases de aquella universidad, que llegó a ser la tercera en Andalucía, después de Sevilla y Granada.

La creación de Colegios Mayores universitarios -Jeréz y Córdoba- no sólo tenía como finalidad la formación de clérigos, sino de un laicado competente y ejemplar que supiese imprimir en la sociedad el cambio necesario para que la vida social se rigiese por los valores del evangelio. La Universidad de Baeza esta destinada a la formación de clérigos. Además fundó once Colegios Menores (Baeza, Ubeda, Beas, Huelma, Cazorla, Andújar, Priego, Sevilla, Jeréz, Cádiz, Écija). Además ayudó en la fundación de otros colegios y sus discípulos crearon a su vez bastantes más. A la nueva forma de educar a los laicos se refiere de una manera especial en las Advertencias al concilio de Toledo ${ }^{82}$ con el objetivo de poderse reformar en sus costumbres: "converná primero examinar todos los maestros que enseñan a leer y escribir en la vida y costumbres, como el Tridentino manda sean examinados los maestros de gramática y de otras ciencias ${ }^{83}$. "Fue un intento no sólo que se criasen hombres de letras, sino también de virtud», nos dice el biógrafo Luis Muñoz ${ }^{84}$. Pide al concilio que recomiende que en

81. Audi, filia (II), 111, 3: I, 775. Cf. J. M. Madruga SAlvadoR, El perfil misionero en San Juan de Ávila, en CEE, El Maestro Ávila. Actas del Congreso Internacional. Madrid, 27-30 noviembre 2000, Madrid 2002, 858.

82. Cf. Advertencias al concilio de Toledo, I, 47: II, 687.

83. Ibid., I, 48: II, 687.

84. LUIS MUÑOZ, Vida, c. $1^{\circ}$, n. 20. 
todos los pueblos se instituyan escuelas no sólo para enseñar religión a los niños, sino para enseñarles a leer y escribir ${ }^{85}$. También recomienda la creación de escuelas nocturnas para los campesinos.

Asimismo, ofrece consejos para ejercer el buen gobierno a los que tienen propiedades o cuentan con personas a su cargo, como es el caso de las cartas 11, 12 y 13. La carta 86 -a la villa de Utrera-constituye un auténtico tratado de cómo se debe llevar la vida de los ciudadanos, de los gobernantes y de todos entre sí.

En cuanto a la no acepción de personas que deben tener los que gobiernan para no tener favoritismos con los más allegados, argumenta San Juan de Ávila interpretando las enseñanzas del evangelio con una sabiduría inigualable. Así dice en la carta 12: "Mas estando en la silla de la cruz dijo a su Madre: Mujer, ve ahí a tu Hijo (Jn 19, 26); para dar a entender que quien está en la silla de persona pública ha de renunciar todo particular amor, aunque de su propia madre sea. Y esto nos dio Él en ejemplo cuando algunas respondía áspero a su Madre bendita, para decirnos cuánto nos debemos guardar de nuestras particulares afecciones, aunque otros se enojen con nosotros, suframos alguna pena, antes que siguiéndolas descontentar a Dios [...] No para hacer ni deshacer pone Dios a los señores, mas para ejecutar las leyes de Dios y de su santa voluntad. Y si se dicen señores, son debajo del universal Señor, en cuya comparación son tan vasallos como sus vasallos y tienen tan limitado el poder como ellos en lo que toca en lo que deben hacer. Aquel, pues, sea más favorecido y querido que más justicia tuviere; y más castigado, que más lo mereciere. Y en esto parecerá el señor al verdadero Señor, que sin aceptar personas (cf. Sab 6, 8), da a cada uno según sus obras; $y$ algunas veces castiga más a los más privados, porque era razón que menos le ofendiesen, y porque no piensen que, por ser amados, han de tomar ocasión de hacer lo que no es razón. Tanto debe durar el amistad cuanto la bondad, y la enemistad cuanto la maldad; porque de otra manera, jay de los que dicen al bien mal y al mal bien! (Is 5, 20).

Debe también vuestra señoría mirar cómo le puso Dios en ojos de muchos, que aquella tienen por regla lo que le vieren a él hacer. Haga cuenta que está puesto en alto y que su habla y vestido y costumbres son de todos miradas y de los más son seguidos. Si un traje se trae en palacio, si una habla se usa, aquello procuran todos de saber. Y si se usase entre señores a quien le da una bofetada parar el otro carrillo (cf. Mt 5, 39), y aborrecer los pecados, y tener por grandeza el obedecer las leyes de Cristo, sin falta los bajos ternían por honra lo que ven usar a los altos. Y, por tanto, creo que de las más ánimas que se pierden son causa prelados de la Iglesia y señores del mundo. Mírese vuestra señoría con cien ojos en cuanto persona particular y con cien mil por ser persona a quien muchos miran y se han de ir tras ella; y tenga su persona y casa tan concertada

85. Memorial segundo al concilio de Trento, 54: II, 579-580. 


\section{Juan de Ávila desde la sociedad y cultura actuales}

con la ley de Cristo, que quien quisiere imitalla, imite a Cristo, y que no halle cosa en que tropezar». Recomiendo vivamente que se lean las partes finales de las cartas 12 y 86.

\section{CONCLUSIÓN}

A lo largo de estas páginas hemos pretendido presentar cómo San Juan de Ávila es una luz imprescindible para la sociedad y cultura actuales. Una sociedad que se encuentra en un proceso de cambio de era, que busca caminos de realización, pero con frecuencia equivocados, pues cree que sólo el hombre se basta a sí mismo para llegar a su plenitud; habiendo por tanto desplazado a Dios de su vida y de su horizonte; con todas las consecuencias que esto trae consigo para la humanidad entera. Ni siquiera los grandes ideales y a veces conquistas positivas como la solidaridad, los derechos humanos, la tolerancia, la paz, la justicia, la igualdad y la dignidad de la persona, independiente de su raza, cultura, religión, etc., se ven garantizados y sostenidos en una base firme si se desplaza a Dios de la sociedad, llegando así en no pocos casos a ser meros anhelos inalcanzables.

En los inicios del camino emancipador del hombre del renacimiento, y también de la sociedad y cultura actuales, San Juan de Ávila brilla con luz propia como modelo de lo que constituye la reflexión y la vivencia de lo auténticamente humano: nuestro encuentro con Dios en el amor. Para él no se trata de tener que optar entre Dios o el hombre, como desgraciadamente se ha planteado el debate, viendo a Dios como contrincante del hombre y como estorbo para su propia realización. Antes bien, el Santo Maestro, con su enseñanza en los más diversos ámbitos -sermones, cartas, dirección espiritual, etc.-y sobre todo con su vida configurada con Cristo, ha sabido manifestar que Dios es la auténtica plenitud del hombre y que el encuentro amoroso con Él nos lleva hasta las más altas cotas de realización humana.

En nuestro mundo secularizado, en el que el hombre postmoderno, ofuscado por el progreso de la ciencia y la técnica, sólo aspira a «vivir como Dios», pero sin Dios, San Juan de Ávila brilla hoy con luz propia para iluminar el auténtico camino de la humanización de nuestro mundo, proponiendo que sólo viviendo nuestra relación de amistad y amor con Dios, en una verdadera actitud de hijos del Padre, en el Hijo, por el Espíritu, podremos llegar a encontrarnos con nosotros mismos y con la plenitud de nuestro ser, estableciendo con los demás una verdadera relación de fraternidad universal, basada no solamente en los lazos de la solidaridad humana, sino en aquellos más fuertes e irrompibles de la fraternidad en Cristo gracias a nuestra condición de hijos en el Hijo.

El Apóstol de Andalucía, adentrándose en la vivencia del misterio del amor de Dios, se convierte así en modelo de creyente y de teólogo que ilumina con su vida y su enseñanza el camino de la evangelización y humanización plena 
en las actuales circunstancias. Podemos decir, por tanto, con todo rigor que San Juan de Ávila, conocido como el Santo Maestro, es, sin duda, no sólo un gran Doctor de la Iglesia Universal sino un gran Maestro para la sociedad y cultura actual. Desde el evangelio, vivido y predicado, ha contribuido, y sigue haciéndolo, a sembrar y expandir, junto a otros grandes hombres y mujeres de la humanidad, la cultura del amor. 